\author{
بررسى تأثير ميزان و زمان مصرف كود نيتروزن بر صفات كمى كلرنخ \\ خاك آهكى در منطقه كرمان \\ هرمزد نقوى '، آرش صباح'، مهدى اميريور رباط' و فريدون نورقلى يور؟

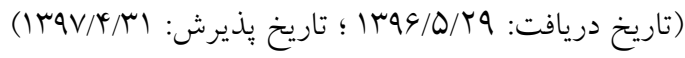

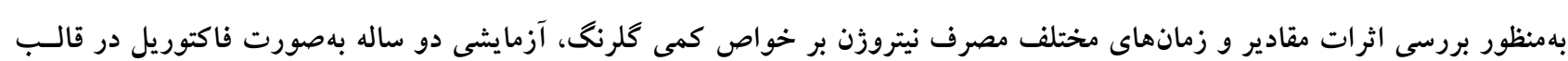

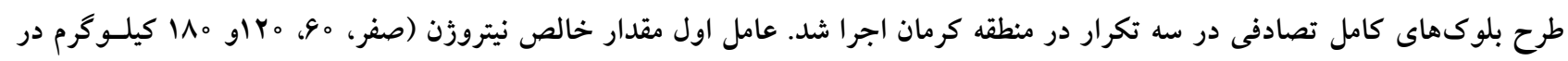

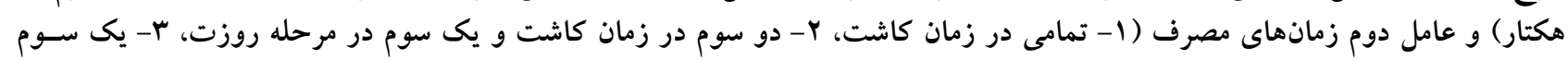

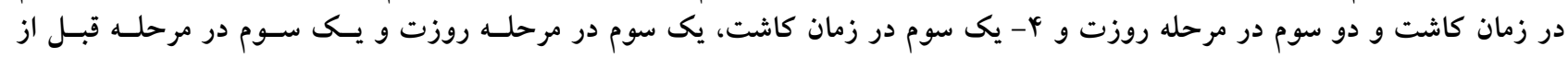

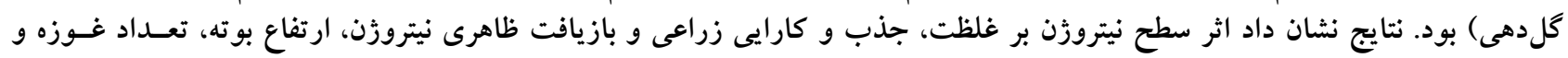

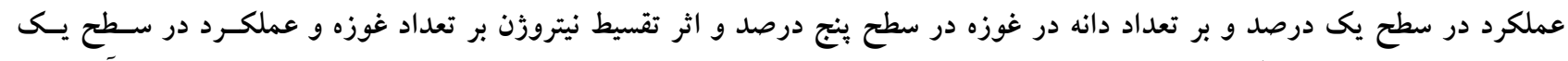

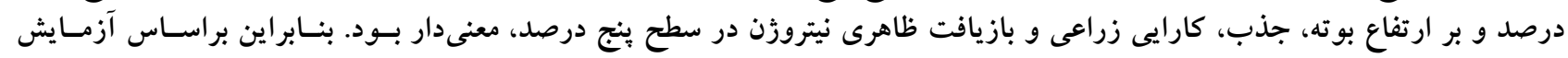

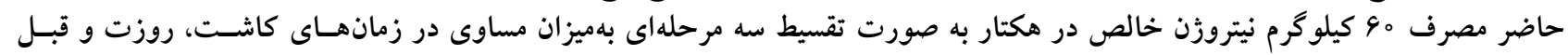

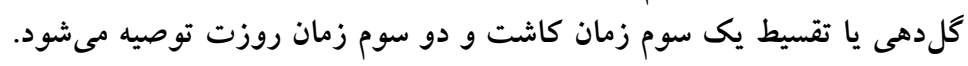

وازههاى كليدى: تقسيط، كلدشت، مقادير نيتروزن

1. بخش تحقيقات خاكى و آب، مركز تحقيقات و آموزش كشاورزى و منابع طبيعى استان كرمان، سازمان تحقيقات، آموزش و ترويج كشاورزى، كرمان، ايران

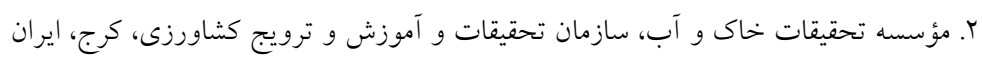

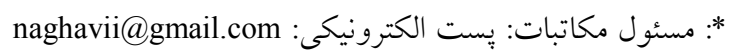


زيسـتمحيطى ايجــاد نكنـــ (4). حيـدرى و آسـاد، در مقدمه تحقيقى با سطوح مختلـف نيتـروزن مشـاهده كردنــ كـهـ

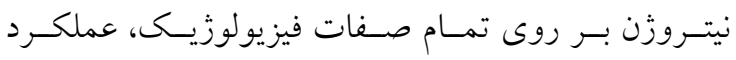

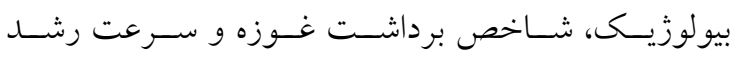
محصول اثر معنى دارى داشته است. آنهـا همجنــين نتيجـه كرفتند كه حداكثر عملكرد دانه از مصسرف مها كيلـو گرم نيتروزن در هكتار بهدست آمده است كه تعـــــــاد دانـه در غوزه تحت تأثير نيتروزن واقع شده و وزن هزار دانه تحت تأثير نيتروزن قرار نحرفت (س). يكى از مهمترين رويكردها براى افزايش كارايى مصرف نيتروزن تأمين كردن نيتـروزن

در زمانى است كه گياه بيشترين نياز را به آن دارد (9). جونز و توكر (19VA) نشان دادند كه نيتروزن افزايش معنىدارى را در تعداد غوزههاى انشعابات فرعى كل آذين، موجب مىشود. در اثر كاربرد كود نيتروزن بوتهها بهمــت طولانىترى فعال مانده و شاخه هاى بيشتر و همجنــين بـــ همان نسبت، غوزههاى بيشـترى توليــ مسىشـود. در ايسن آزمايش تعداد دانه در غوزه تحت تـأثير نيتـروزن افـزايش

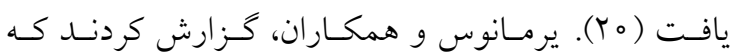

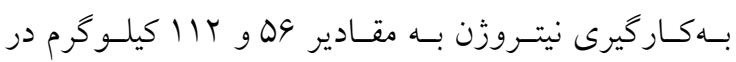
هكتار عملكرد دانه را بهطور معنى دارى در مقايسه با عـدم مصرف نيتروزن افزايش داد امـا اخـتلاف معنسىدارى بـين عملكرد دانه در اين دو مقدار نيتـروزن مصـرفى بـهدسـت نيامد (Tr). هازرا و تريڤياتى، در مقايسـه سـطوح مختلـف

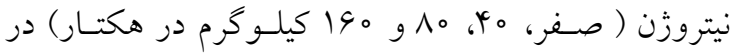
يك خاك سنذى لوم غير آهكى، با غلظت نيتـروزن خـاك

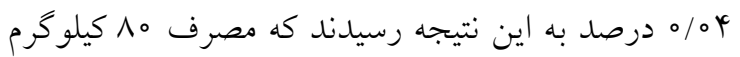

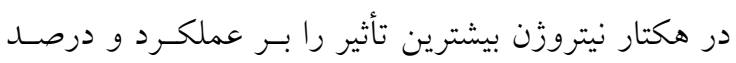

$$
\text { روغن گلرنخ بهجاى گذاشت (19). }
$$

ديكسيت و ياداوا، در ايالت ماديـا يــرادش هندوسـتان

خاكى با بافت متوسط سطوح مختلف نيتروزن (صفر، مه،

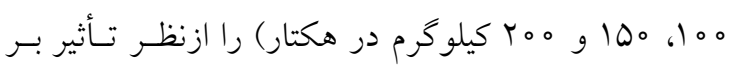

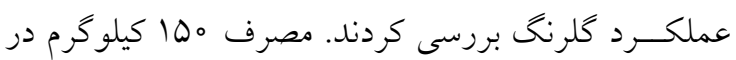

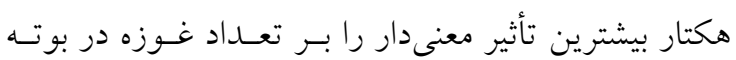

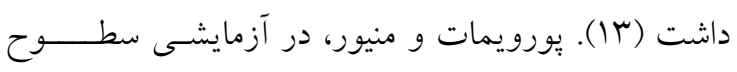

كلرنغ با نام علمى (Carthamus tinctorius L.) گياهى از تيره مركبان (Asteraceae)، از قديمىترين دانههاى روغنى

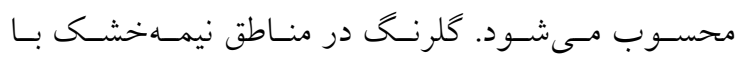

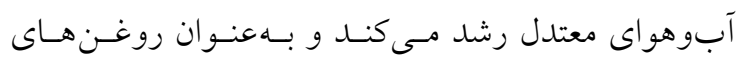

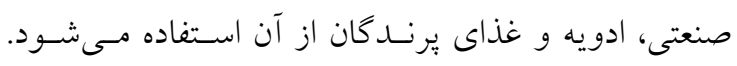

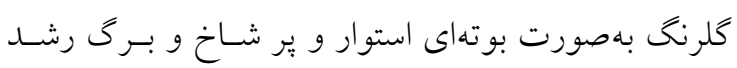

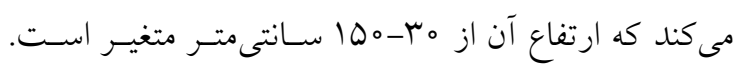

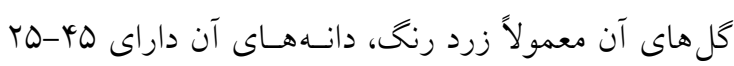

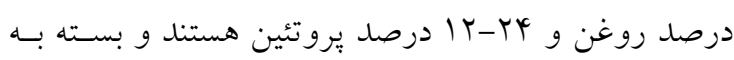

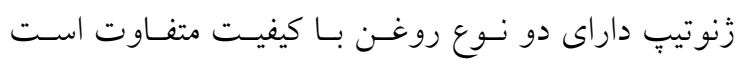

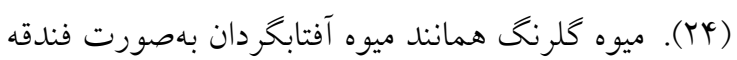
بوده و از نظر شكل شـبيه يـك دانـه كوجـــ آفتـابكردان

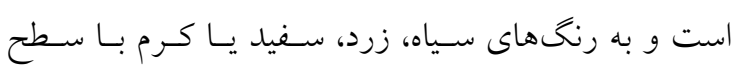
خارجى صاف ديده مىشود. ذخيره روغن در لِه ها انجـام

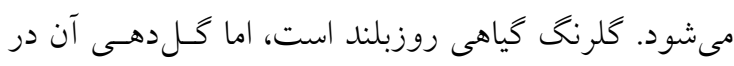
هواى گرم بهميزان قابلتوجهى جلو مسى افتـد. كلرنــ بـا

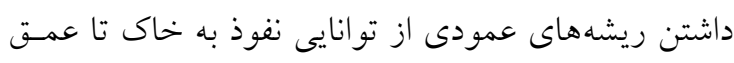
دو تا سه متر برخوردار است و به گرما نيز مقاوم اسـت و در صورت وجود رطوبت كافى در خاك مىتواند حرارت حدود of درجه سانتى گراد را تحمل كند و نسبت به ساير كياهان روغنى ديخر، مقاومت زيادترى دارد، همجِنسين بـهـ

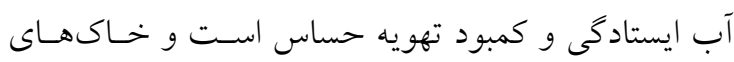
عميـق، داراى بافـت متوسـط و اسـيديته حسـود ختثـى را ترجيح مىدهد (11). مصرف روغن در ايران در طى سالهاى اخير بـهدليـل افزايش رشد جمعيت و افزايش مصـرف سـرانه، افـزايش

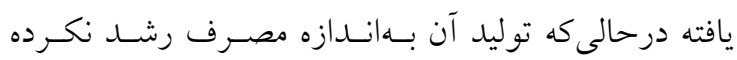
است. نياز كودى كلرنخ با توجه به عملكرد مـورد انتظـار

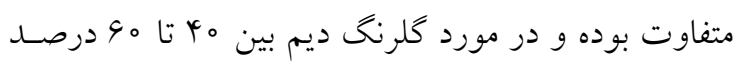

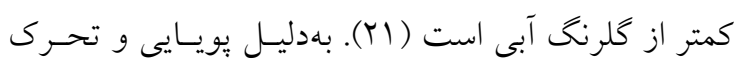
نيتروزن در خاك، مديريت مصرف آن از اهميـت ويـزّهاى برخوردار است تا حداكثر عملكرد عايد و كيفيت محصول نيز بهتر شده و مصرف نيتروزن اثرات تخريبسى در مسـائل 
مختلف دنيا و ايران بر روى كلرنخ مشخص مىشـود كـه شرايط آبوهوايى، خاك هر منطقه و نوع رقـم در تعيسين سطح مناسب نيتروزن اثر دارد و از طرفى در منطقه كرمان،

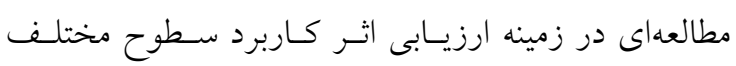

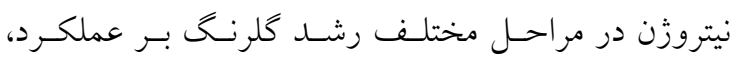

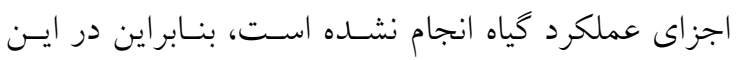
تحقيق اين موضوع مورد بررسى قرار كرفت.

\section{مواد و روشها - (- ماد}

بهمنظور بررسى اثرات مصرف مقادير و زمانهاى مختلـف

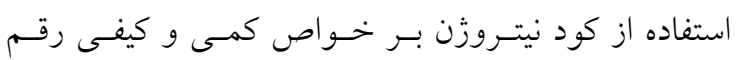
كلدشت كلرنخ، آزمايشى دو ساله در ايستخاه تحقيقـات

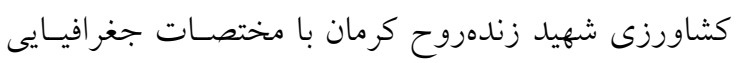

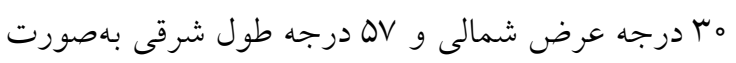

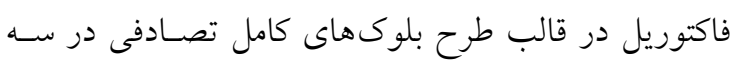

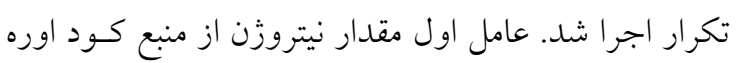

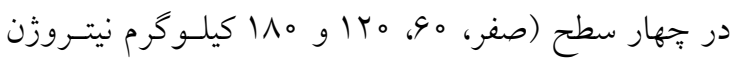

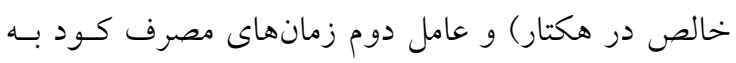

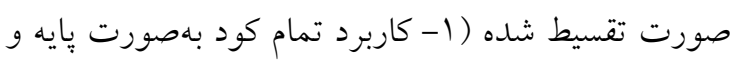
در زمان كاشت r- كاربرد دو سوم كود در مرحلـه بِايسه و

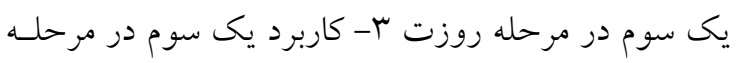

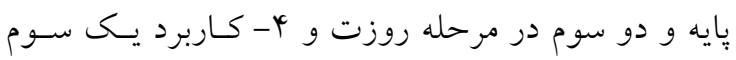

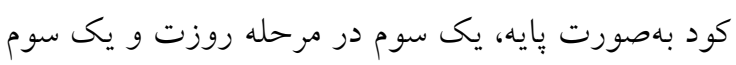
در مرحله قبل از كل دهى) بود.

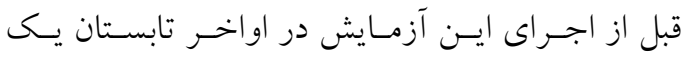

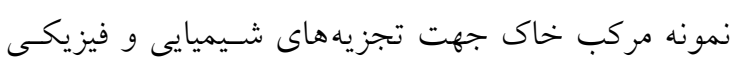

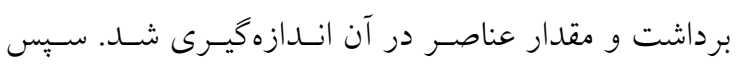

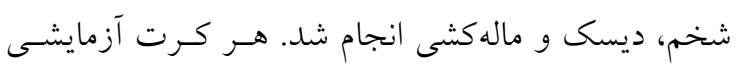

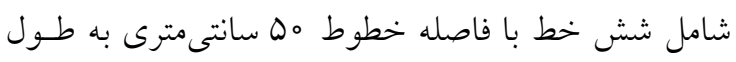

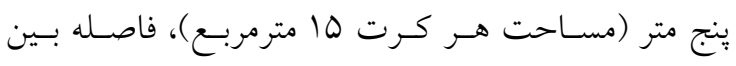
كرتها يك متر و بين تكرارها جهار متـر در نظـر كرفتسه

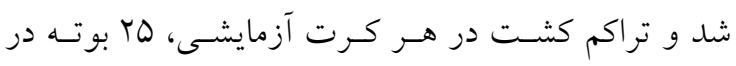

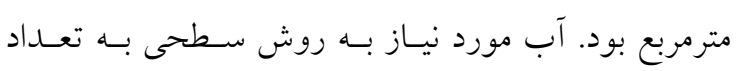

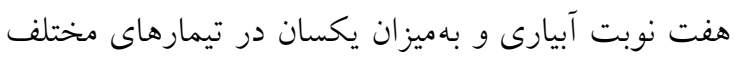

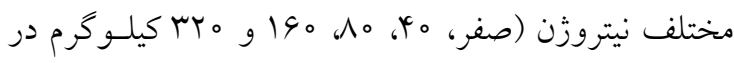
هكتار) را مطالعه كردند. اين محققان به اين نتيجه رسيدند

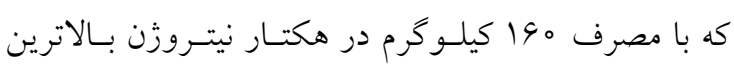

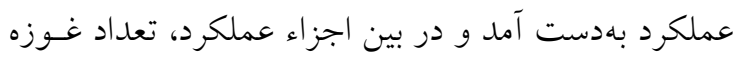

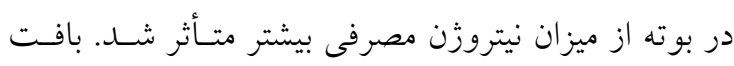

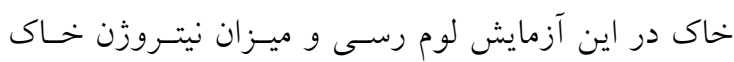
(TQ) (TQ)

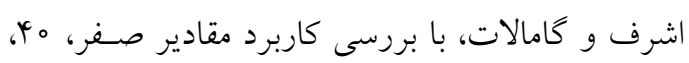

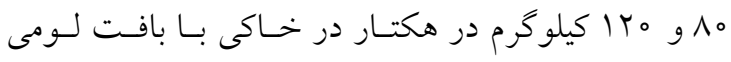

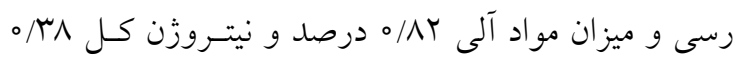

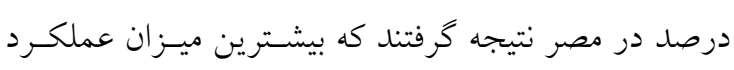

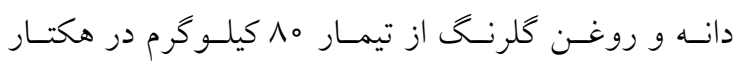

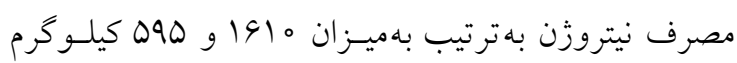

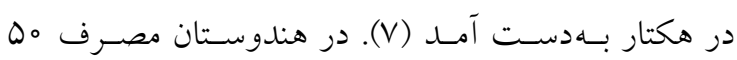
درصد نيتروزن مورد نياز بـهــورت كـود شسيميايى و D0 درصد مابقى بهصورت ورمسى كميوستت، بيشـترين ميـزان

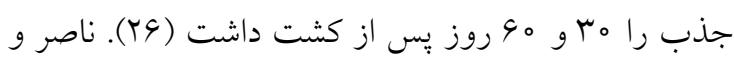

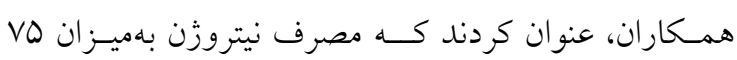

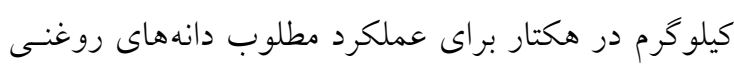
و يروتئين كافى است (Y) (Y)

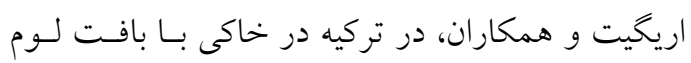

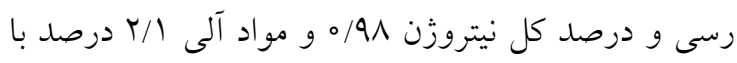

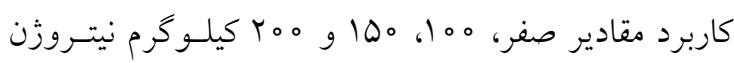

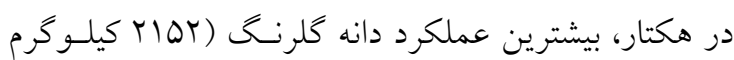

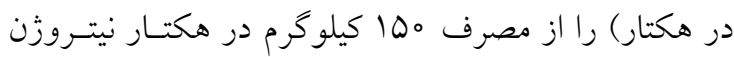

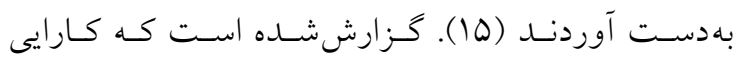

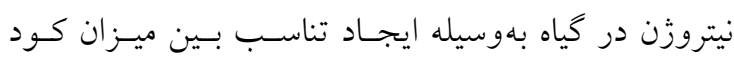

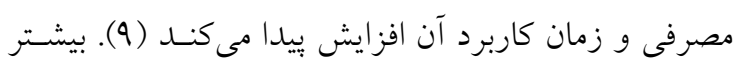

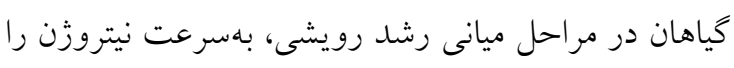

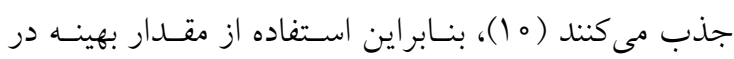
زمان مناسب، مهمترين راهكار براى افزايش عملكرد دانه و

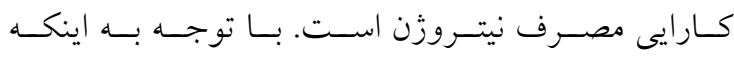

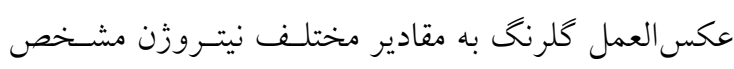

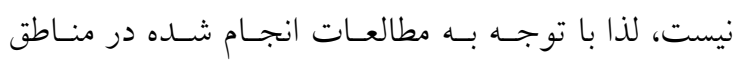


ارائه شد. براى اثر اصلى طبق روال معمول محاسبات انجـام

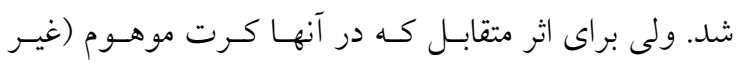

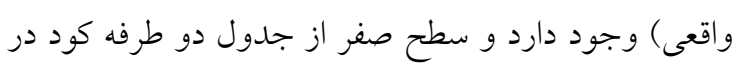
فرمول مصرف، حذف شد. با توجه به اينكـه تفـاوت ميـان

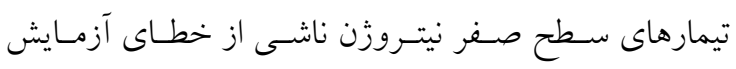

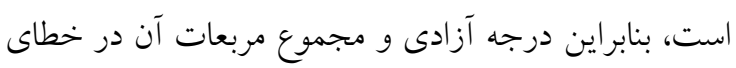

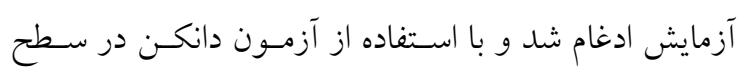
احتمال ينج درصد مقايسه ميانخين تيمارها انجام شد (1) (1).

\section{نتايج}

نتايج برخى خصوصيات فيزيكى و شسيميايى خـاك محـل

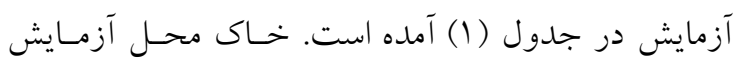
آهكى، غير شور (قابليت هدايت الكتريكى كمتـر از جهـار

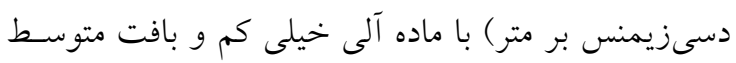
تا نسبتاً سنخين بود. با توجه به نتايج بهدست آمده در جدول (Y) بود، اثـر سـال

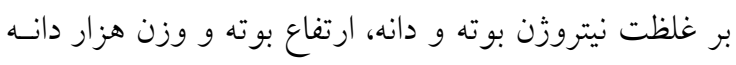

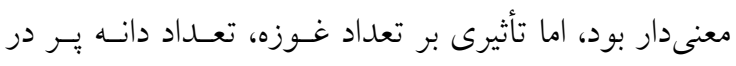

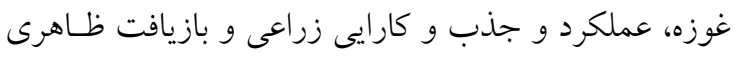
نيتروزن نداشت. اثر اصلى سطح نيتروزن بر غلطت نيتـروزن

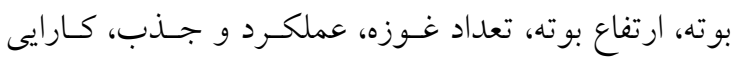

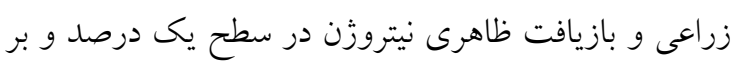

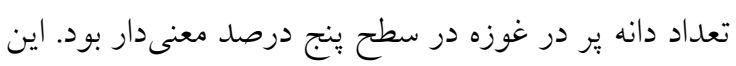
اثر بر وزن هزار دانه و غلظت نيتروزن دانـه معنسى دار نبـود.

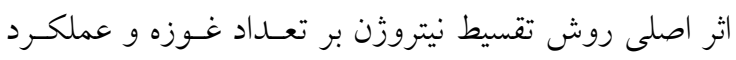

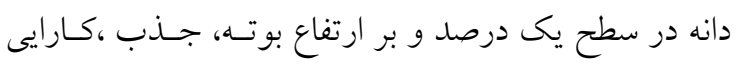

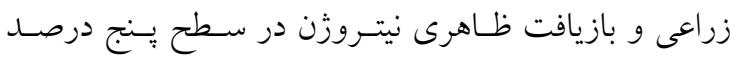

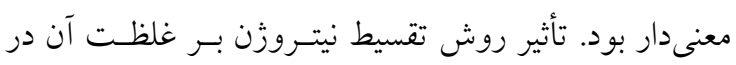

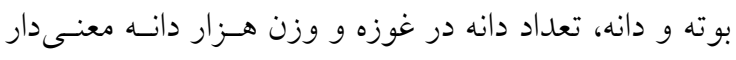
نبود. اثر متقابل سطوح در نحوه تقسيط كود نيتروزن بر هيج

يكى از صفات مورد بررسى معنى دار نبود (جدول ب ب).

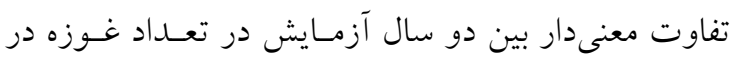
مترمربع، تعداد دانه در غوزه و ميزان عملكرد دانه، جذب داب، كارايى زراعى و بازيافت نيتروزن وجود نداشـت. بـهدليـل
در اختيار گياه قرار گرفت. بين تكرارهـا فاصـله كـافى در

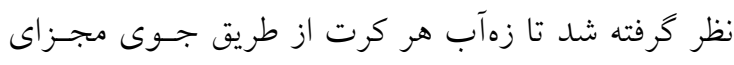

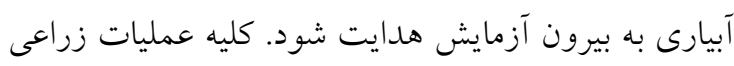

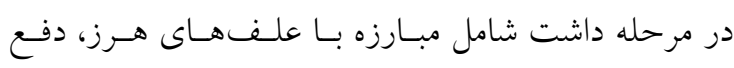

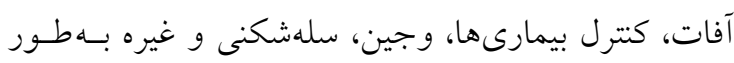
منظم و يكنواخت براى كرتها انجام كرفت.

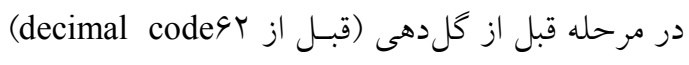

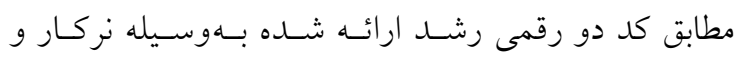
همكاران و قبل از مصرف كود تقسيط نيتروزن، بينج نمونه كياه از اندام هوايى تهيه و غلظت و جذانب نيتسروزن در آن آن

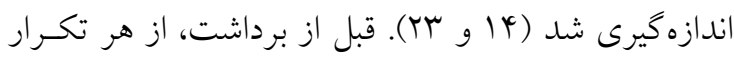

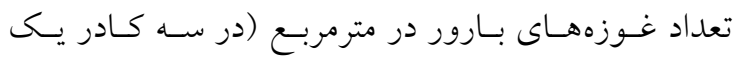

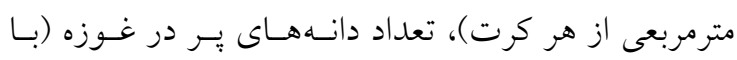

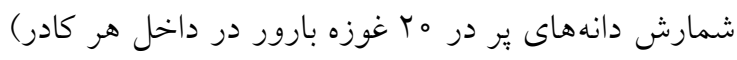

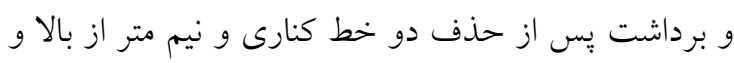

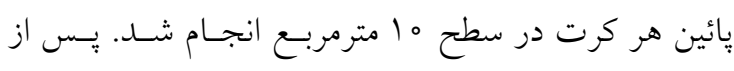
برداشت، وزن هزار دانه (با سهبار شـمارش از سـه كـروه

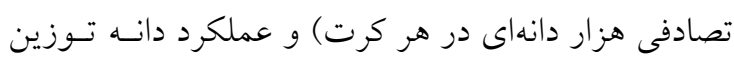

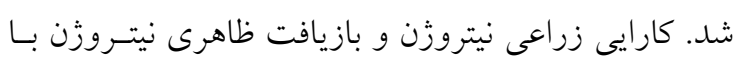

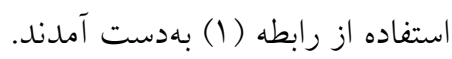
$\mathrm{NAE}=(\mathrm{Ynx}-\mathrm{Yn} 0) / \mathrm{Nf}$

در اين رابطه NAE = كارايى زراعى نيتروزن (كيلو گرم بـر

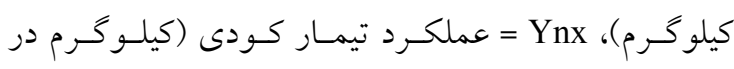

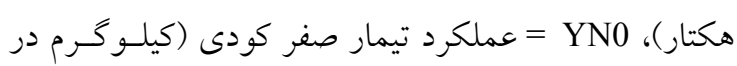
هكتا و NF = كل نيتروزن مصرفى (كيلـو كـرم در هكتـار)

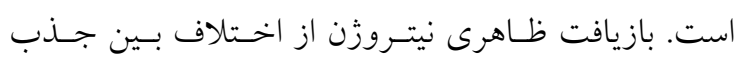

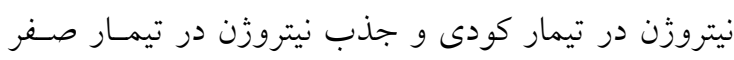

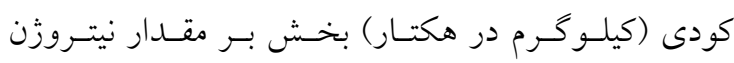
مصرفى (كيلوكرم در هكتار) بهدست آمد.

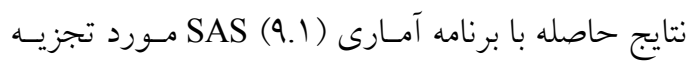

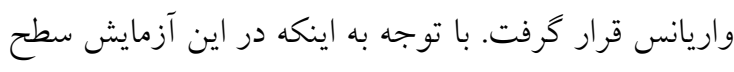

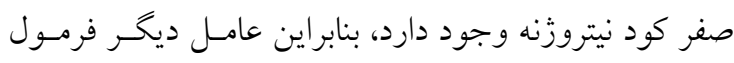
مصرف در اين سطح متعير نيست (كرتهـاى موهـومى يـا

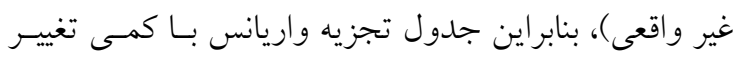


جدول ا. برخى خصوصيات فيزيكى و شيميايى قطعات آزمايش قبل از اعمال تيمارها

\begin{tabular}{|c|c|c|c|c|c|c|c|c|c|c|c|c|}
\hline \multirow{2}{*}{ بافت } & $\mathrm{Cu}$ & $\mathrm{Mn}$ & $\mathrm{Zn}$ & $\mathrm{Fe}$ & $\mathrm{K}$ & $\mathrm{P}$ & $\mathrm{N}$ & O.C & $\mathrm{CaCO}_{r}$ & $\mathrm{EC}$ & \multirow{2}{*}{$\mathrm{pH}$} & \multirow{2}{*}{ منطقه } \\
\hline & \multicolumn{7}{|c|}{$\left(\mathrm{mg} \mathrm{kg}^{-1}\right)$} & \multicolumn{2}{|c|}{$(\%)$} & $\left(\mathrm{dS} \mathrm{m} \mathrm{m}^{-1}\right)$ & & \\
\hline سيلتى لوم & $0 / r$ & 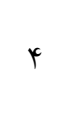 & 1 & $\Delta$ & $10 \circ$ & 9 & $\mu_{0}$ & $\circ / 1$ & 19 & $r / \mathcal{T}$ & $V / \mathcal{C}$ & زيستخاه شهيد \\
\hline
\end{tabular}

معنى دار نبـود. بــا افـزايش سـطوح كـود نيتروزنـه ميـزان عملكرد دانه كلرنخ بالا رفت، كمترين ميزان عملكــرد در

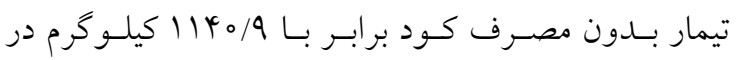
هكتار بود. تفـاوت بـين سـطوح كـودى 9. كيلو گرم نيتروزن در هكتار از لحاظ عملكرد دانه، معنى دار نبود (جدول ץ). در بررسىهاى شريعتىنيا و سليمانى نيـز افزايش مصـرف نيتـروزن عملكـــد دانسه، تعـداد طبـق در

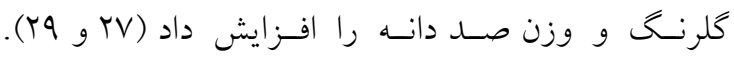
بررسى هاى شارما و ورما نيز نشان دادنــــ كـهـ بــا افـزايش

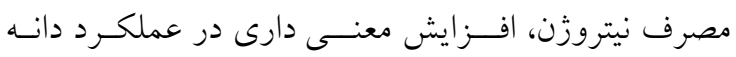
كلرنـع ناشسى از افـزايش وزن دانسه رخ مسىدهـــ (Y^). جاكر الحسينى گزارش كرد كه كاربرد نيتروزن تا سـط كيلوگرم در هكتار نيتروزن خالص، سبب افزايش معنى دار

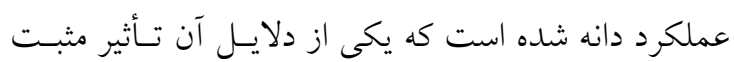
نيتروزن در افزايش تعداد طبق در بوته است (1). كـاربرد م1/ كيلـو گرم نيتـروزن در هكتـار، بيشـترين ميزان جذب نيتروزن را داشت كه تفاوت آن با سطحهـاى يائين تر معنى دار بود. كمترين ميزان از تيمـار صـفر سـطح

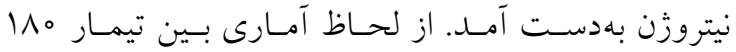

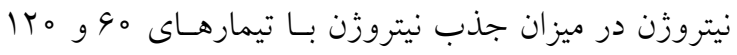
نيتروزن، تفاوت معنىدارى بود اما تفـاوت بـين دو سـطح كـاربرد هو و ه rا نيتــروزن در ميـزان جـــب نيتــروزن معنى دار نبود (جدول r). نتايج جدول (r) نشان داد كه ارتفاع بوته كلرنخ زمـانى كه تمام كود نيتروزنه همزمان با كشت مصرف شود كمتر از ساير روشهاى تقسيط است و بيشترين ارتفــاع از مصـرف نيتروزن بهميزان يكسوم زمان كاشت و دوسوم زمان روزت

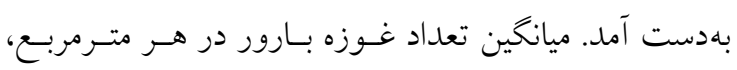

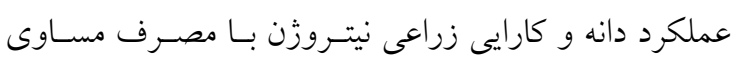

متفاوت بودن دو سال از لحاظ شرايط آبوهوايى، برخسى صفات نظير وزن هزار دانه، ارتفاع بوته و غلظت نيتـروزن در دو سال آزمايش متفاوت بودند و مقادير اين صفات در سال دوم بيشتر بود (جدول ץ). مقادير غلظت نيتروزن در مرحله قبل از گل دهى و دانـه بين تيمار شاهد (بدون مصرف كود) و سطوح كودى ديخـر معنى دار نبود. با مصرف كود نيتروزنـهـ و افـزايش مقـدار آن ارتفاع بوته كلرنخ افزايش يافت. اين تفـاوت بـين سـطوح

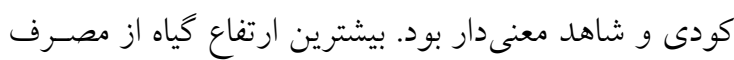

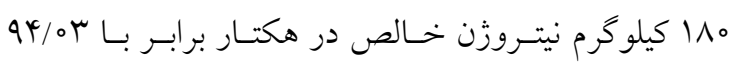
سانتى متر و كمترين آن از تيمار بدون مصرف كود برابـر بـا

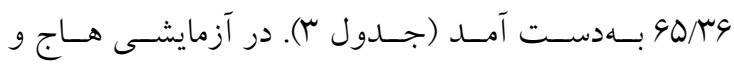
همكاران، گزارش كردنـــ كـهـ بـا افـزايش عرضـه نيتــروزن ارتفاع بوته بهطور معنى دارى افـزايش بيـــا مسى كنــد و ايسن افزايش ارتفاع ناشى از رشد طـولى سـلولهــاى سـاقه و در

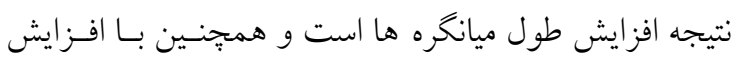
نيتروزن تا سطح هبا كيلو گرم در هكتار، تعداد دانـه توليـد شده در طبقها افزايش مىيابد (IV).

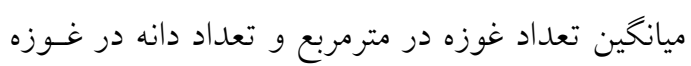
با مصرف كود نيتروزنه بهطور معنىدار افزايش يافـت، امـا بين سطوح نيتروزن استفاده شده اين تفاوت معنىدار نبـود

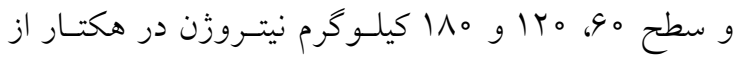
اين لحاظ در يك گروه آمارى قرار گرفتنـد. در آزمايشـى آبل، گزارش كرد كه مصرف نيتروزن تعداد دانه در طبق را

بهور جشمخيرى افزايش مى جهد (ه). بيشـترين وزن هـزار دانسه در سـطح كـودى مو كيلـو كرم

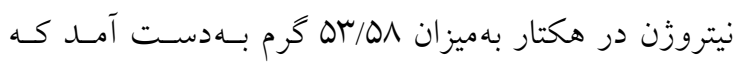
تفاوت آن با تيمار شاهد معنى دار شد. اما با ديخـر سـطوح

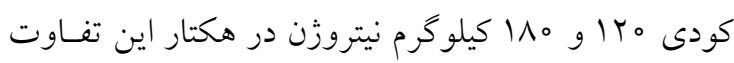




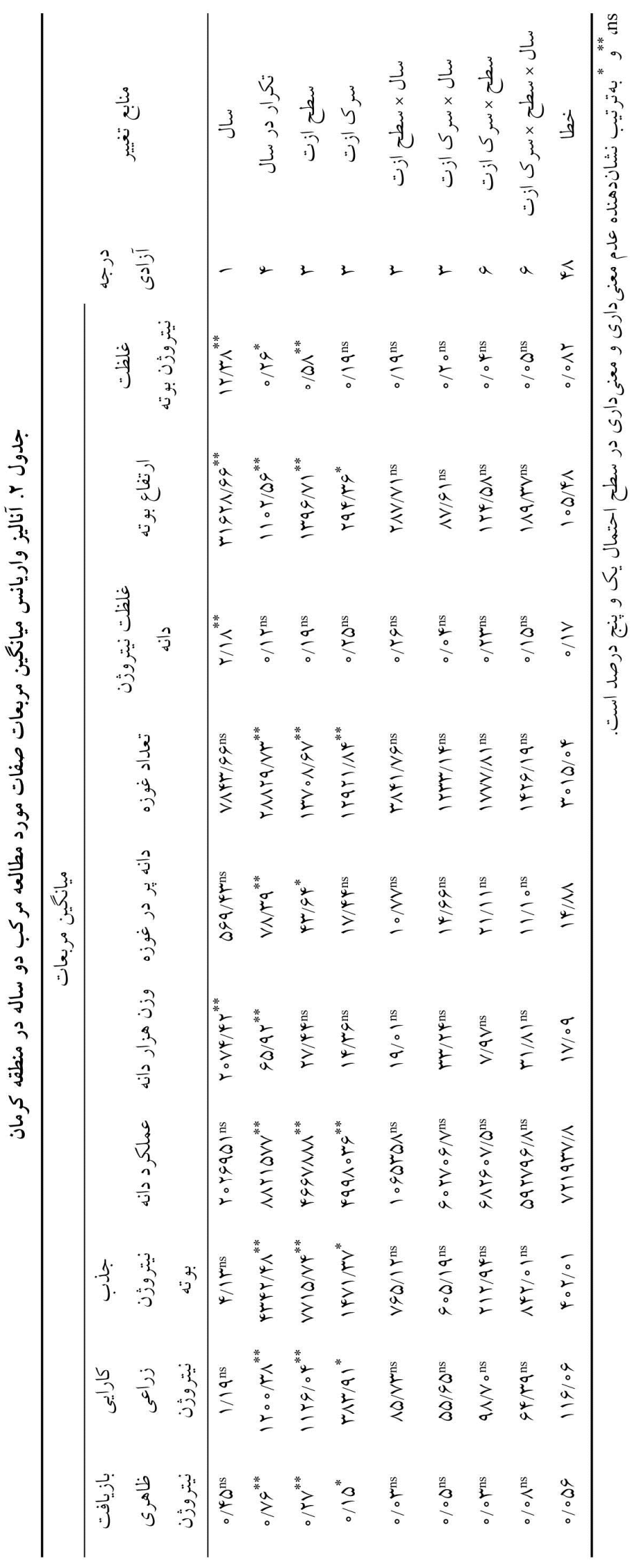




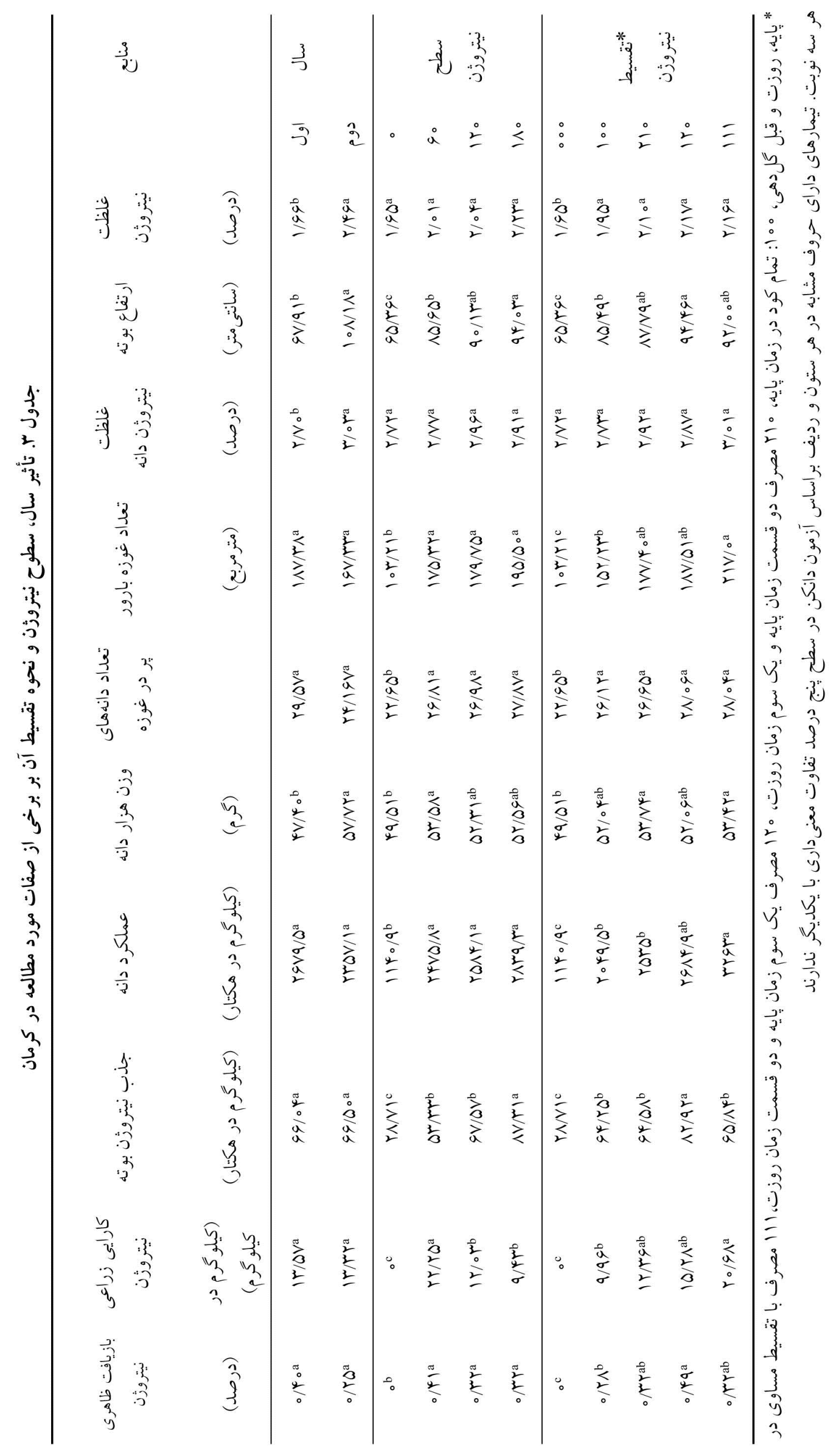




\section{جدول f. تأثير تيمار سطوح نيتروزن و نحوه تقسيط بر برخى از صفات مطالعه شده در كرمان}

\begin{tabular}{|c|c|c|c|c|c|}
\hline بازيافت ظاهرى & كارايى زراعى نيتروزن & جذب نيتروزن بوته & (كيلو كرم در هكتار ) & سطح تقسيط & (كيلو گرم در هكتار) \\
\hline$\circ^{c}$ & $\circ \mathrm{e}$ & TA/VIe & $1140 / 9 x^{c e}$ & 。 & 。 \\
\hline$\circ / \Gamma \Delta^{b c}$ & $19 / \mathrm{V} y^{\mathrm{abc}}$ & $\mu \mathrm{pr} / 9 q \mathrm{de}$ & $r r Y \Delta / \mathrm{VV}$ bcd & 100 & 90 \\
\hline$\circ / \mathcal{f}_{0} \mathrm{ab}$ & $|\Psi / \Delta|^{\text {bcde }}$ & Or/Y $\&$ de & $1901 / 99 \mathrm{cde}$ & rlo & 90 \\
\hline$\circ / 90^{a}$ & $r Y / \Delta V^{a b}$ & $q Y / \Delta q^{b c d}$ & $\Upsilon q \mid Q / \Gamma \wedge^{\mathrm{abcd}}$ & $1 r_{0}$ & 90 \\
\hline$\circ / \uparrow_{\circ} a b$ & $\Gamma / / \Delta^{a}$ & $\Delta r / \Delta V^{d e}$ & $\mu_{0} \mid 0 / T V^{a b c}$ & 111 & 90 \\
\hline$\circ / Y V^{b c}$ & $\varphi / V \mathrm{~d}^{\mathrm{e}}$ & $G \circ / V l^{\mathrm{cd}}$ & $|V \circ \Lambda / \mathcal{G}|^{\mathrm{de}}$ & 100 & $r_{0}$ \\
\hline $0 / T V^{b c}$ & $\mid \& / \& q$ bcde & $91 / T_{0} \mathrm{~cd}$ & $T M M \circ / \mathcal{G} V^{a b c}$ & rlo & kro \\
\hline$\circ / Q \circ a b$ & $11 / 1$ rbcde & $\Lambda \Lambda / \Lambda \Lambda^{a b}$ & $Y \Psi \wedge V / T$ rabcd & Iro & rro \\
\hline $0 / Y^{b} \mathrm{bc}$ & IV/N rabcd $^{\mathrm{a}}$ & $\Delta q / \nvdash \vee c d$ & $r r \& q / / \wedge^{\mathrm{ab}}$ & 111 & Kro \\
\hline a سMab & $\Delta / \Psi_{0}$ cde & $\Lambda \Lambda / \Gamma \Delta^{\mathrm{ab}}$ & $r \| r / 99^{c d e}$ & 100 & 110 \\
\hline 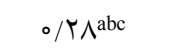 & $9 / \circ$ qcde & $\Lambda \circ / \circ q^{a b c}$ & YVVY/AYabcd & rlo & $1 \wedge 0$ \\
\hline$\circ / r V^{a b}$ & $10 / 1 /$ bcde & $9 \Delta / r_{\circ} a$ & ras // rabc & Kro & $1 \wedge 0$ \\
\hline$\circ / T^{a b}$ & $|\Psi /| \Delta^{\text {bcde }}$ & $\Lambda \Delta / \uparrow q a b c$ & $r \Delta \circ q / 4 r^{a}$ & 111 & 110 \\
\hline
\end{tabular}

تيمارهاى داراى حروف مشابه در هر ستون و رديف براساس آزمون دانكن در سطح بنج درصد تغاوت معنىدارى با يكديكر ندارند.

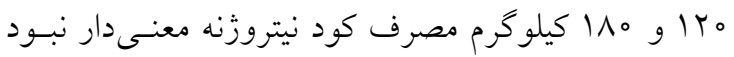

(شكل r). براساس نتايج بهدست آمـده از محققــان ديخـر نظير حقيقـت نيـا، سـوبرامانيان و كولانــاجويو، اسـتنباط مىشود كه اين امر بهدليل بـايين بـودن سـطح كوديـذيرى

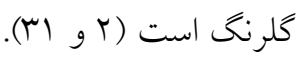

ميانخين كارايى زراعى نيتروزن در تقسيط مصرف

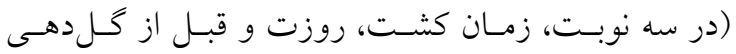
بهلصورت مساوى) بيشترين ميزان بود و اين ميـزان نسـبت

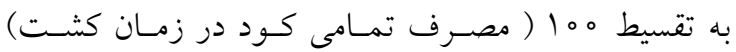
معنى دار بود. بيشترين بازيافت ظاهرى نيتروزن از تقسيط

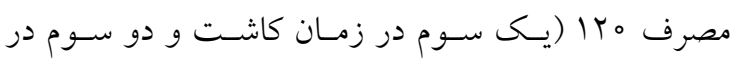

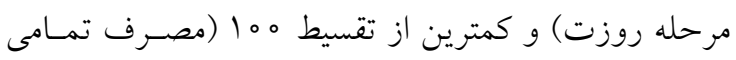

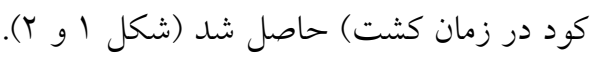

بحث

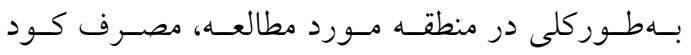
نيتروزنى باعث افزايش عملكرد محصول شــه اسـت كـهـ
كود نيتروزنـه در هـر سـه زمـان كاشـت، روزت و قبـل از

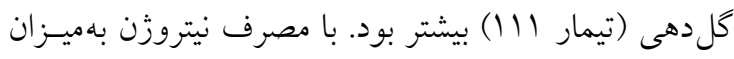
يكسوم زمـان كاشـت و دو سـوم زمـان روزت، بيشـترين

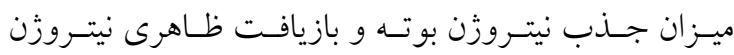

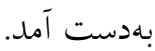
نتايج مقايسـه ميـانخين اثـر متقابـل سـطح مصـرف و تقسيط كود نيتروزن در جدول (Y) نشان داده شده اسـت.

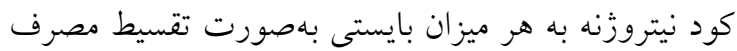

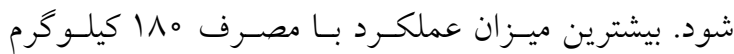
نيتروزن در هكتـار بـهـهورت تقسيط مسـاوى در زمـان كاشت، روزت و قبل از كلدهى (111) بهدست آمد.

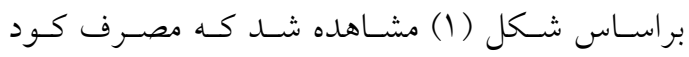

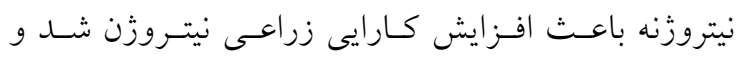

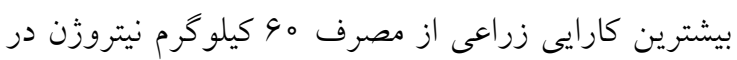
هكتار بهدست آمد كه با ديخر سطوح كودى از نظر آنس آمارى

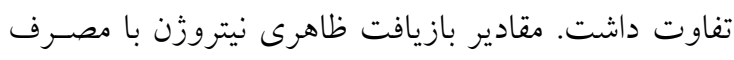

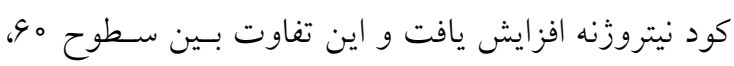


(ب)

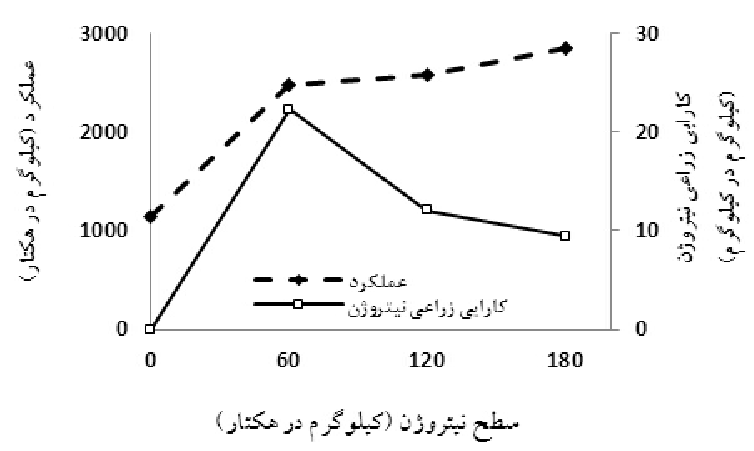

(الف)

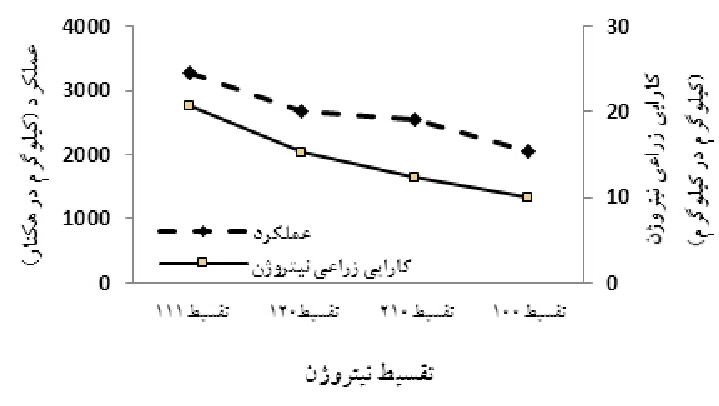

شكل ا. مقايسه كارايى زراعى نيتروزن و عملكرد دانه گلرنگ در: الف) سطوح تقسيط و ب) مصرف نيتروزن

(ب)

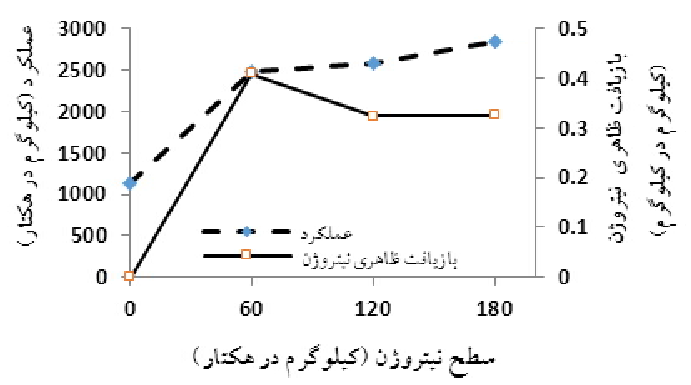

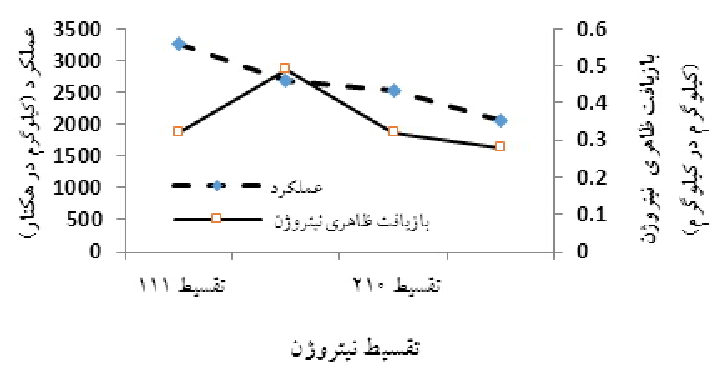

شكل r. مقايسه بازيافت ظاهرى نيتروزن و عملكرد دانه گلرنح در: الف) سطوح تقسيط و ب) مصرف نيتروزن

محصول، مناسبتر از كاربرد يكبـاره آن در زمـان كاشـت محصول است (r). اسـتير و هاريخــان عنـوان كردنـــ كـهـ بهترين عملكرد دانسه بـا مصسرف ر || كيلـو گرم نيتـروزن بهصورت يـكدوم قبـل از كاشـت و يـكدوم در مرحلــ غنجهه دهى بهدست آمد (مب)، علاوهبر اين افـزايش ميـزان نيتروزن و كاربرد آن در دفعات بيشتر باعث طولانى شـدن دوره رشد رويشى شده كه مىتواند تشكيل آسـميلاتهـا، اختصاص آنها به ساقه و درنهايت ارتفاع گيـاه را بـه طـور قابل توجهى تحت تأثير قرار دهــ (9). همجنــين جـونز و تاكر به اين نتيجه رسيدند كه درصورتى كه ميـزان نيتـروزن خاى كمتر از حد بحرانسى باشـد، مصسرف ه ما كيلـو گرم نيتروزن در هكتار سبب افزايش معنى دارى در تعـداد دانسه در طبق مىشود (Yo). در اين تحقيق كاربرد هو كيلوگرم نيتروزن خـالص در هكتار از لحاظ عملكرد در يك خـروه آمـارى بـا سـطوح
اين افزايش ناشـى از تـأثير نيتـروزن بــر اجـزاى عملكــــ محصول كلرنخ بهويزه افزايش تعداد غوزه و تعـداد دانسه در غوزه است و محققان مختلف نيز اين تأثير را خـزارش كردند. در تحقيقى زائو و همكاران (ه०ه Y) و دل ياسـو و همكاران (Y०V) بيان داشتند كه كاربرد نيتروزن بـر روى اجزاء عملكرد كلرنـع تـأثير كذاشـته و در بيشـتر مـوارد باعث افزايش آنها نسبت به شاهد شده اسـت (سب و Y I).

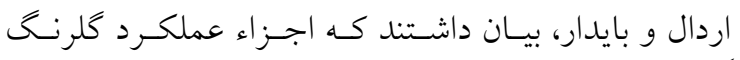
بهطور معنى دارى تحت تأثير سطوح مختلف نيتروزن قـرار

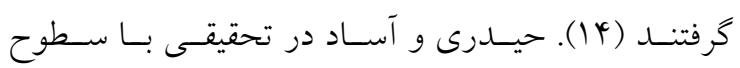

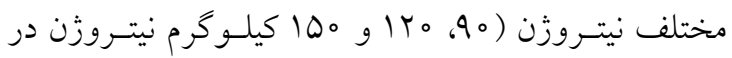
هكتار) بر روى كلرنخ رقم زرقان TV9، مشاهده كردند كه نيتروزن بر روى تمام صفات زراعى از جمله تعداد طبق و سرعت رشد محصول اثر معنى دارى داشته است، همحِنين كاربرد جنهد مرحلهاى كود نيتروزنه در طول زمـان داشـت 


$$
\begin{aligned}
& \text { كـزارش كردند، مصرف ه كيلـو گرم نيتـروزن در هكتـار }
\end{aligned}
$$

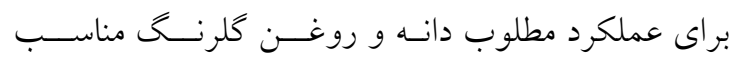

$$
\begin{aligned}
& \text { است (YT). مشابه اين نتسايج يسيش از ايسن توسـط جهـاد } \\
& \text { عبادى و همكاران، گزارش شده است (19). } \\
& \text { نتيجه كيرى } \\
& \text { براساس اين تحقيق در منطقه كرمان، كـاربرد ه9 كيلـوكرم } \\
& \text { نيتروزن خالص در هكتـار، معـادل هما كيلـوگرم اوره در } \\
& \text { هكتار، براى كلرنخ رقم گلدشت توصيه شد كـه بايسـتى } \\
& \text { آن را بهصورت تقسيط در سه نوبت، زمان كشـت، روزت } \\
& \text { و قبل از كل دهى بهصورت مساوى يا تقسـيط يـى سـوم } \\
& \text { زمان كاشت و دوسوم زمان روزت مصرف شود. }
\end{aligned}
$$

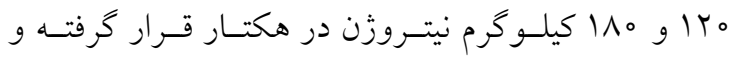$$
\text { تفاوت معنى دارى با آنها ندارد. بيشترين كـارايى زراعى و }
$$$$
\text { بيشترين بازيافت ظاهرى نيتروزن با مصسرف هو كيلـوررم }
$$

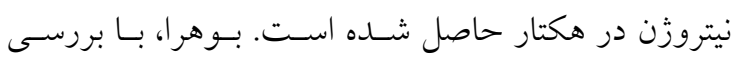$$
\text { سطوح مختلف نيتـروزن بـه ايسن نتيجـه رسـيد كـه كـود }
$$

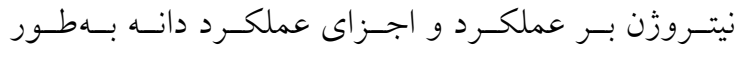$$
\text { معنى دارى اثر دارد، بهطورىكه عملكرد دانه با كاربرد كود }
$$$$
\text { نيتروزن بهطور ميانخين } 9 \text { ادرصد نسبت به شاهد افـزايش }
$$$$
\text { يافته بود و بيشترين عملكــرد دانـهـ را ميـزان هو كيلـوكرم }
$$$$
\text { نيتروزن خالص در هكتار ايجـاد كـرده بـود (^). ناصـر و }
$$$$
\text { VD همـكاران عنوان كردند كـــهـ مصرف نيتروزن بـهـيـزان }
$$$$
\text { كيلوگرم در هكتار براى عملكرد مطلوب دانه هاى روغنى }
$$$$
\text { و يـروتئين كـافى اسـت ( (Y). نـــصر و همكـــاران نيـز }
$$

\section{منابع مورد استفاده}

ا. جاكرالحسينى، م. هیبا. اثرات نيتروزن و فسفر بر عملكرد كمى و كيفى كلرنخ در شرايط ديم نيمه كرمسيرى. مجلسه علـوم

$$
\text { خاك و آب IV-rQ }
$$

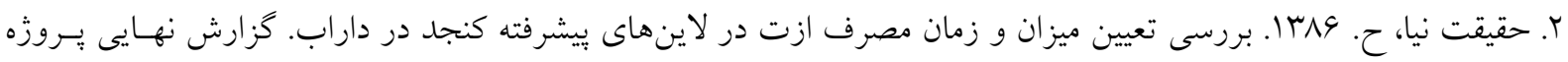

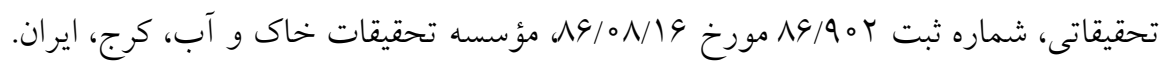

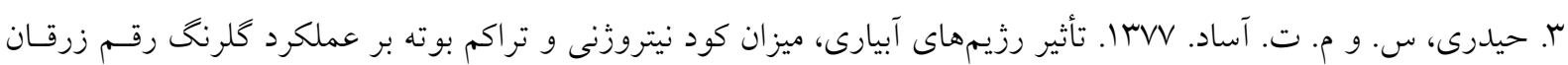
و rVq در منطقه ارسنجان. ينجمين كنخره زراعت و اصلاح نباتات ايران، انتشارات مؤسسه تحقيقات اصلاح و تهيه نهال و

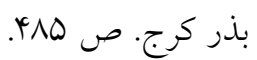

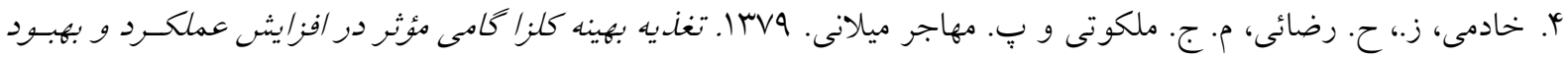

$$
\text { كيغيت روغن (توصيه كودى براى توليدكنناكان كلزا در خاكهاى كشور). نشر آموزش كشاورزى، كرج، ايران. }
$$

5. Abel, G. H. 1976. Effects of irrigation regimes. Planting dates, nitrogen levels, and row spacing on safflower cultivars. Agronomy Journal 68: 448- 451.

6. Amanullah, K., B. Marwat, P. Shah, N. Maula and S. Arifullah. 2009. Nitrogen levels and its time of application influence leaf area, height and biomass of maize planted at low and high density, Pakistan Journal of Botany 41(2): 761-768.

7. Ashraf, A. A. and O. M. Gamalat. 2013. Modeling the influence of nitrogen rate and plant density on seed yield, yield components and seed quality of safflower. American Journal of Experimental Agriculture 3(2): 336-360.

8. Bohra, J. S. 1995. Effect of nitrogen, planting pattern and population on productivity of safflower + Indian rape intercropping. Agronomy Journal 51: 371-373.

9. Bohra, G. 2000. Effect of levels of nitrogen and row spacing in safflower. 63(23): 652 .

10. Bybordi, A. 2007. Effects of Nitrogen and phosphorus rates on cultural Circumestances, grain yield and fat contents. Pajouhesh and Sazandegi 80: 186 - 194. (In Farsi).

11. Christos, A. D. and S. Christos. 2008. Safflower yield, chlorophyll content, photosynthesis, and water use efficiency response to nitrogen fertilization under rain fed conditions. Industrial Crops and Products 27: $75-85$.

12. Del Poso, A., P. Perez, D. Gutierrez, A. Alonso, R. Morcuende and R. Martinez- arrasco .2007. Gas exchange acclimation to elevated $\mathrm{CO} 2$ in upper-sunlit and lower-haded canopy leaves in relation to 
nitrogen acquisition and partitioning in wheat grown in field chambers. Environmental and Experimental Botany 53: 371-380.

13. Dixit, J. P. and H. S. Yadava. 1995. Response of safflower to levels of nitrogen and irrigation under medium texture soils of Madhya Pradesh. Advances in Plant Sciences 8(1): 100-102.

14. Erdal, E. and H. Baydar. 2005. Deviations of some nutrient concentrations in different parts of safflower cultivars during growth stages. Pakistan Journal of Botany 37(3): 601-611.

15. Eryiğit, T., B. Yıldırım, A. M. Kumlay and S. Sancaktaroğlu. 2015. The Effects of Different Row instances and Nitrogen Fertilizer Rates on Yield and Yield Components of Safflower (Carthamustinctorious) Under Micro-Climate Conditions of Iğdır Plain-Turkey. In: Proceeding of the $3^{\text {rd }}$ International Conference on Biological, Chemical and Environmental Sciences, Kuala Lumpur, Malaysia.

16. Hazra, C. R. and S. B. Tripathi. 1986. Influence of nitrogen on some soil properties and forage production of safflower and Chinese cabbage with and without tree association. Journal of Indian Society of Soil Science 34(2): $275-280$

17. Hoag. B. K., J. C. Zubriski and G. N. Geiszler. 1968. Effect of fertilizer treatment and row spacing on yield, quality and physiological response of safflower. Agronomy Journal 60: 198-200.

18. Jane, R. C. and R. Srivastava. 2007. Factorial Experiment-Some Variations. I.A.S.A.I. Library Avenue, New delhi-110012. PP. 389-392.

19. Jehad Abbadi, A., J. Gerendás and B. Sattelmacher. 2007. Effects of nitrogen supply on growth, yield and yield components of safflower and sunflower. Plant Soil 306(1-2): 167-180.

20. Jones, J. P. and T. G. Tucker. 1978. Effect of nitrogen fertilizer on yield, nitrogen content and yield components of safflower. Agronomy Journal 60: 363-364.

21. Naser, H. G., N. Katkhud and L. Tannir. 1978. Effect of fertilization and population rate- spacing on safflower yield and other characteristics. Agronomy Journal 70: 683- 684.

22. Nasr, H. G., N. Katkhud and L. Tannir. 2003. Effect of fertilization and papulation rate- spacing on safflower yield and other characteristics. Agronomy Journal 72:683-684.

23. Nerkar, Y. S., S. S. Narayanan, D. M. Hegde, P. S. Pathak, H. S. Sen, R. K. Chowdhury, S. S. Banga, A. K. Singh and P. S. Bhatnagar. 2006. Guidelines for the Conduct of Test for Distinctiveness, Uniformity and Stability on Safflower. International Union for the Protection of New Varieties of Plants, Geneva, Switzerland.

24. Omidi, H., A. Soroushzadeh, A. Salehi and F. A. D. Ghezeli. 2005. Rapeseed germination as affected by osmopriming pretreatment. Agricultural Sciences and Technology 19(2): 125-136.

25. Purvimath, S. S. and G. R. Manure. 1993. Effect of fertilizer levels of N, P, S and B on the seed and oil yield of safflower on vertisol. Journal of the Indian Society of Soil Science 41(4): 780-781.

26. Raol, P. C., A. Pratap and K. Rajesh. 2013. Effect of INM practices on nutrient uptake and seed yield in safflower. Annals of Biological Research 4(7): 222-226

27. Shariatinia, F. 2008. Effects of nitrogen, boron and sulfur on yield and yield components, seed protein and oil content of safflower, Isfahan native cultivar. MSc. Thesis. Faculty of Agriculture. Shahid Bahonar University of Kerman. Kerman.

28. Sharma, K. and A. Verma. 2002. Effect of plant population and row spacing on sunflower agronomy. Canadian Journal of Plant Science 75: 491-499.

29. Soleimani, R. 2009. Study of rates and timing of nitrogen application on yield and yield components of spring safflower. Iranian Journal of Agricultural Sciences 10(1): 47-59.

30. Steer, B. T. and E. K. S. Harrigan. 1986. Rates of nitrogen supply during different developmental stages affect yield components of safflower. Field Crops Research 14(3): 221-232.

31. Subramanian, A. S. S. and R. Kulandaiveive. 1997. Yield of Sesamum (Sesamum indicum L.) to nitrogen fertilizer application. Indian Agriculturalist 23: 43 - 49.

32. Yermanos, D. M., B. J. Hall and W. Burge. 1964. Effect of manganese and nitrogen on safflower and flax seed production and oil content and quality. Agronomy Journal 56: 582-585.

33. Zhao, D., R. K. Reddy, V. G. Kakani and V. R. Reddy. 2005. Nitrogen deficiency effects on plant growth, leaf photosynthesis and hypespectral reflectance properties of sorghum. European Journal of Agronomy 22: 391-403. 


\title{
The Investigation of the Effect of Rate and Time of Nitrogen Application on the Quantity Characteristics of Safflower in Calcareos Soil in Kerman Area
}

\author{
H. Naghavi ${ }^{1 *}$, A. Sabbah ${ }^{1}$, M. Amirpour robat $^{1}$ and F. Nourgholipour ${ }^{2}$
}

(Received: August 20-2017 ; Accepted: July 22-2018)

\begin{abstract}
This study was conducted based on a randomized complete block design and a factorial experiment with three replications in regions to investigate the effect of different rates and times of nitrogen on the quantitative properties of safflower. The first factor was different nitrogen rates including $0,60,120$ and $180 \mathrm{~kg} \mathrm{ha}^{-1}$, and the second one was nitrogen application time including seed sowing, rosette and the before flowering stage; these were $1-0-0,1 / 3-2 / 3-0$, $2 / 3-1 / 3-0$ and $1 / 3-1 / 3-1 / 3$ with the Goldasht variety. The results showed that nitrogen rate had a significant effect on all studied traits. Nitrogen application time also had a significant effect on capitulum number and yield at $p>0.99$ and on the length of plant, nitrogen adsorption, agronomic efficiency and apparent recovery at $p>0.95$. So based on the results, the recommended consumption of $60 \mathrm{~kg} / \mathrm{ha} \mathrm{N}$ was split into three equal amounts at the time of planting, rosette and flowering or 1/3-2/3-0, in Kerman area.
\end{abstract}

Keywords: Goldasht, Nitrogen rate, Split

1. Soil and Water Research Department, Kerman Agricultural and Natural Resources Research and Education Center, AREEO, Kerman, Iran.

2. Soil and Water Research Institute, Agricultural Research Education and Extention Organization, AREEO, Karaj, Iran.

*: Corresponding Author, Email: naghavii@gmail.com 